DOI: 10.46340/eppd.2020.7.3.34

Maryna Kleiman

ORCID ID: https://orcid.org/0000-0002-9760-3873

Odesa State University of Internal Affairs, Ukraine

\title{
THE FEATURES OF PRIVATE DETECTIVE (SEARCH) ACTIVITY
}

\author{
Марина Клейман \\ Одеський державний університет внутрішніх справ, Україна

\section{ОЗНАКИ ПРИВАТНОЇ ДЕТЕКТИВНОЇ (РОЗШУКОВОЇ) ДІЯЛЬНОСТІ}

It is investigated that the main features of private detective (search) activity are: activity of separate professionally trained persons and their associations; carrying out activities on a legislative basis (in accordance with the principles of domestic legislation in those areas in which private detectives work); directing activities to ensure the legal rights and interests of individuals and legal entities; engaging in private detective (search) activities with the permission of the licensing authority; carrying out business activities, on a paid contractual basis; operation in accordance with the concluded agreement between the subjects of private detective (search) activity and customers (clients); the subject of the contract is to provide the customer with a wide range of comprehensive information.

Keywords: private detective (search) activity, concept and features, private detectives, legislative activity, business, licensing.

Постановка проблеми. Визначення ознак того чи іншого поняття дозволяє зафіксувати його істотні, суттєві, невід'ємні властивості. У широкому розумінні поняття закріплюють загальні ознаки загальних предметів і явищ, у вузькому - ознаки предметів чи/або явищ, які відносяться до певної сфери суспільних відносин. Зміст поняття тісно пов'язаний з його ознаками, за якими здійснюється його визначення. Визначення ознак поняття, його змісту та обсягу забезпечує дієвість наукового дослідження та вироблення пропозицій щодо удосконалення відповідної практичної діяльності.

Поняття та ознаки приватної детективної (розшукової) діяльності активно розглядається як науковцями, так i законодавцем, про що свідчить наявність більше десяти законопроектів, розробленими в основному народними депутатами. Аналіз наукових визначень показує різні підходи до такого визначення, основними ознаками вказаної дефініції називаються: суб'єктний склад (приватні детективи та їх об’єднання), платна договірна основа (підприємництво), захист законних прав та інтересів фізичних і юридичних осіб. Не має особливих суперечностей між доктринальними визначеннями та тими, що містяться в законопроектах, мова йде лише про більш широке чи вузьке розуміння такої діяльності, визначення тих чи інших іiі ознак як основних. Вважаємо недоліком наведених дефініцій відсутність чіткої вказівки на відповідність приватної детективної (розшукової) діяльності законодавчим засадам та законодавчим вимогам, окрім того варто було б вказувати на надання дозволу на зайняття такої діяльності уповноваженим органом.

Стан дослідження. Різнобічні аспекти приватної детективної (розшукової) діяльності досліджують вітчизняні та зарубіжні дослідники: І. Беззуб, Е. Бекірова, А. Волинська, В. Горовенко, Ю. Орел, А. Юрченко та інші. Однак у комплексному вигляді ознаки приватної детективної (розшукової) діяльності науковцями не розглядаються, що актуалізує предмет дослідження.

Метою статті $\epsilon$ комплексне 3'ясування та визначення основних ознак приватної детективної (розшукової) діяльності.

Виклад основного матеріалу. У широкому розумінні приватна детективна (розшукова) діяльність є діяльністю приватних детективів та їх об'єднань із забезпечення законних прав та інтересів фізичних та юридичних осіб відповідно до законодавчо визначених засад та вимог за дозволом уповноваженого органу на платній договірній основі, та така, що здійснюється 
за договором про детективні послуги, предметом якого $є$ надання замовникові інформації з розшуку людей та майна, його бізнес-інтересів, захисту в досудовому та судовому порядку. Розглянемо ознаки приватної детективної (розшукової) діяльності приймаючи до уваги, що одним із визначень «ознака» Великий тлумачний словник сучасної української мови наводить - рису, властивість, особливість кого, чого-небудь; те, що вказує на що-небудь, свідчить про що-небудь; показник, свідчення ${ }^{1}$.

До ознак приватної детективної (розшукової) діяльності віднесемо:

1) діяльність окремих спеціально професійно підготовлених осіб та їх об'єднань;

2) здійснення діяльності на законодавчій основі (водночас і відповідно до спеціального закону i відповідно до засад вітчизняного законодавства у тих сферах, в яких працюють приватні детективи); осіб;

3) спрямування діяльності на забезпечення законних прав і інтересів фізичних та юридичних

4) зайняття приватною детективною (розшуковою) діяльністю за дозволом уповноваженого органу;

5) здійснення підприємницької діяльності, ознакою якою є іï платна договірна основа;

6) iï здійснення відповідно до укладеного договору між суб'єктами приватної детективної (розшукової) діяльності та замовниками (клієнтами);

7) предметом договору $\epsilon$ надання замовникові широкого кола різнобічної інформації. Розглянемо наведені ознаки більш детально.

I. Зазначеною діяльністю повинні займатися спеціально підготовлені фахівці- приватні детективи. У цьому питанні суперечності між науковцями і розробниками законопроектів не має, про те є окремі дискусії щодо юридичної освіти чи будь-якої іншої вищої, а також щодо певного стажу та перепідготовки. Науковці не завжди погоджуються із необхідністю наявності саме юридичної освіти та спеціальної практики. До таких поглядів віднесемо висловлювання А. Юрченко та А. Усенко, які вказують, що вимога вищої юридичної освіти є недоречною, оскільки для успішного надання детективних послуг юридична освіта зовсім не обов'язкова. Детективна діяльність має більше спільного з оперативно-розшуковою роботою, ніж зі слідчою, а працівники оперативних підрозділів в Україні, як правило, вищої юридичної освіти не мають ${ }^{2}$. також таке: на сьогодні деякі навчальні заклади, зокрема Дніпропетровський державний університет внутрішніх справ, здійснюють підготовку фахівців за спеціальністю 262 «Правоохоронна діяльність», спеціалізації «Приватна детективна діяльність», «Безпека підприємства», які за задумом суб'єктів надання освітніх послуг мають право на зайняття приватною детективною діяльністю. Однак ця спеціальність не відноситься до юридичної, а низка юридичних дисциплін, які викладаються, $є$ значно меншими, як і отримання навичок та знань майбутніми приватними детективами. Науковець робить слушний висновок, що спеціальна фахова детективна підготовка не потрібна тим, хто вже має юридичну освіту ${ }^{3}$.

Вважаємо вимогу щодо обов'язковості юридичної освіти цілком доцільною. Зазначена діяльність повинна здійснюватись чітко і відповідно до законодавчих положень, знання вітчизняного законодавства $є$ обов'язковим для приватного детектива. Підкреслимо, що вища юридична освіта забезпечить більшу ефективність діяльності приватних детективів, тісно пов'язана 3 необхідністю дотримуватись правових норм, не порушення законодавчих вимог щодо, зокрема, стеження за особою, розшук фактів для судового розслідування, доказування неправомірності використання торгівельної марки тощо.

II. Щодо здійснення на законодавчій основі приватної детективної (розшукової) діяльності, то вкажемо, що на сьогодні спеціального закону не прийнято, однак це не означає, що приватні детективи не мають законодавчого орієнтиру і їх діяльність $€$ такою на власний розсуд. Наведемо такі приклади. Обов'язковим для приватних детективів $є$ знання та дотримання норм Цивільного кодексу

\footnotetext{
${ }^{1}$ Бусел, В.Т. (2004). Великий тлумачний словник сучасної украӥнської мови. Київ: Ірпінь, 665.

2 Юрченко, А.О., Усенко, А.О. (2018). Проблеми легалізації інституту приватної детективної діяльності в Україні. Міжнародний юридичний вісник: актуальні проблеми сучасності (теорія та практика), 3-4 (12-13), 133.

${ }^{3}$ Орел, Ю.В. Деякі питання правового статусу приватного детектива.

$<$ http://er.dduvs.in.ua/bitstream/123456789/1623/1/30.pdf $>$.
} 
України при укладені договору про надання детективних послуг; Господарського кодексу України вразі зайняття детективною діяльністю, яка за своїм змістом є підприємницькою; Кримінального кодексу України під час розшуку зниклої особи; фінансового законодавства, якщо йде мова про перевірку підрозділу юридичної особи з питання приховування частину свого прибутку; процесуального законодавства у випадку пошуку фактів для підтвердження позову та ін.

III. Зазначена діяльність повинна бути спрямована на забезпечення законних прав та інтересів фізичних та юридичних осіб, тобто може характеризуватися як правоохоронна. О.Скакун законний інтерес (інтерес, охоронюваний законом) визначає як простий юридичний дозвіл, що закріплений у законі або випливає із його змісту та виражається у можливостях суб'єкта права користуватися конкретним соціальним благом, а іноді звертатися про захист до компетентних державних органів або громадських організацій - з метою задоволення своїх потреб, які не суперечать суспільним. До їх ознак вчена відносить: 1) правову природу, що укладена в юридичному дозволі (можливості) та відповідає принципу «дозволено все, що прямо не заборонено законом; 2) спрямування на задоволення потреб, що не суперечать суспільним відносинам: 3) вираження у можливості суб'єкта користуватися конкретним соціальним благом; 4) передбачення можливості у деяких випадках звертатися по захист до компетентних державних органів або громадських організацій. відсутність обов'язку, який би відповідав йому та який би задовольняв його (на відміну від суб'єктивного права ${ }^{1}$. Законними правами та інтересами фізичних та юридичних осіб, є ті, що встановлені українським законодавством, вони конкретизуються відповідно до сфери суспільного розвитку чи галузі діяльності.

Зокрема відповідно до Конституції України громадяни мають широке коло прав, серед яких, право на життя, право на охорону здоров'я, право на безпечне для життя і здоров'я довкілля, право на свободу та особисту недоторканність, право на недоторканність особистого і сімейного життя, право на повагу до гідності та честі, право на таємницю листування, телефонних розмов, телеграфної та іншої кореспонденції, право на недоторканність житла, право на вільний вибір місця проживання та на свободу пересування, право на свободу літературної, художньої, наукової i технічної творчості ${ }^{2}$.

Інші матеріальні та особисті немайнові права особи закріплені іншими законами України, так Цивільний кодекс України встановлює право фізичної особи на здійснення підприємницької діяльності (ст.50), спростування недостовірної інформації щодо неї (ст.277), особисту недоторканість (ст.289), донорство (ст.290), недоторканість ділової репутації (ст.299), особисті папери (ст.303), приватну власність (ст.325), інтелектуальну власність (ст. 418), укладання договору (ст.628), спадкування (ст. 1223) та інші ${ }^{3}$.

Відповідно до Цивільного процесуального кодексу України фізична особа має право на звернення до суду за захистом (ст.4), на перегляд справи та оскарження судового рішення (ст.17), ознайомлюватися з матеріалами судової справи, подавати докази, заяви та клопотання, користуватися іншими процесуальними правами (ст.43), відмовитися від позову, збільшити або зменшити розмір позовних вимог, подати зустрічний позов (ст.49) та інші права ${ }^{4}$. Захист зазначених та інших законних прав та інтересів фізичної особи здійснюють приватні детективи у разі укладення договору про надання таких послуг із замовниками.

В.Горовенко називає такі ознаки недержавної правоохоронної діяльності приватних детективів і охоронних організацій: а) охоронні і розшукові послуги надаються заінтересованими особами на оплатній основі за допомогою юридичних засобів; б) застосовувані засоби юридичного впливу повинні відповідати приписам законів або інших правових актів; в) приватна розшукова i охоронна діяльність реалізується в установленому законом порядку із дотриманням певних процедур для забезпечення реалізації і захисту прав і законних інтересів фізичних та юридичних

\footnotetext{
${ }_{1}^{1}$ Скакун, О.Ф. Теорія держави і права. <https://pidruchniki.com/1378122543144/pravo/zakonniy_interes_yogo_ spivvidnoshennya_subyektivnim_pravom_yuridichnim_obovyazkom>.

${ }^{2}$ Конституиія Украйни 1996 (Верховна Рада України). Офіційний веб-сайт Верховної Ради Украйни.

$<$ http://gov.ua/laws/show/254к/96-вр>.

${ }^{3}$ Цивільний кодекс Украӥни 2003 (Верховна Рада України). Офіиійний веб-сайт Верховної Ради Украӥни.

$<$ https://zakon.rada.gov.ua/laws/show/435-15>.

${ }^{4}$ Цивільний прочесуальний кодекс Украӥни 2004 (Верховна Рада України). Офіиійний веб-сайт Верховної Ради

України. <https://zakon.rada.gov.ua/laws/show/1618-15\#n6402>.
} 
осіб; г) діяльність розшукових і охоронних організацій забезпечується не державним примусом, а засобами відповідальності, що випливають з цивільно-правових зобов'язань сторін за договором; д) діяльність розшукових і охоронних організацій не повинна порушувати права і законні інтереси фізичних та юридичних осіб ${ }^{1}$.

IV. Зайняття приватною детективною (розшуковою) діяльністю за дозволом уповноваженого органу. Ліцензування $\epsilon$ засобом державного регулювання провадження видів господарської діяльності, що підлягають ліцензуванню, спрямоване на забезпечення реалізації єдиної державної політики у сфері ліцензування, захист економічних і соціальних інтересів держави, суспільства та окремих споживачів ${ }^{2}$. Ліцензування певних видів господарської діяльності науковці вважають за доцільне розглядати удекількох аспектах: як елемент легітимації суб'єктів господарської діяльності; як умову здійснення певних видів господарської діяльності; як підставу виникнення права здійснювати види господарської діяльності, що підлягають ліцензуванню; як елемент механізму реалізації конституційного права на підприємницьку діяльність; як засіб державного регулювання господарської діяльності ${ }^{3}$.

Щодо приватної детективної діяльності, то зауважимо, що у спеціальному Законі України «Про ліцензування видів господарської діяльності» від 2.03.2015 р. № 222-VIII, такого виду діяльності не наводиться. Однак про необхідність отримання дозволу на таку діяльність вказується і у відповідних законопроектах і у наукових працях.

V. Приватна детективна (розшукова) діяльність є підприємницькою. Законодавчо підприємництво визначено як самостійна, ініціативна, систематична, на власний ризик господарська діяльність, що здійснюється суб'єктами господарювання (підприємцями) з метою досягнення економічних і соціальних результатів та одержання прибутку. Такі їі ознаки як самостійність щодо визначення напрямів своєї діяльності, розпорядження майном, систематичність, ініціативність, легальність, діяльність на власний ризик, отримання прибутку $є$ притаманними також приватній детективній (розшуковій) діяльності. Окрім того, приватні детективи як суб'єкти детективної (розшукової) діяльності характеризуються наявністю спеціальної компетентності, вмінням професіонально орієнтуватися унепередбачуваних та складних ситуаціях, приймати оперативні рішення, бути кваліфікованими менеджерами. Підкреслимо, що суб'єкти приватної детективної (розшукової) діяльності є підприємцями та водночас надають істотну допомогу іншим суб'єктам підприємницької діяльності, зокрема у вивченні репутації та фінансового стану позичальників та інших партнерів, їх спроможності реально виконувати взяті на себе фінансові зобов'язання, що у значній мірі запобігає укладанню ризикованих угод та ухиленню боржників від сплати заборгованості ${ }^{5}$.

Однією із основних ознак зазначеної діяльності як підприємницької $є$ іiі платна договірна основа. Аналіз діяльності детективних агентств свідчить, що матеріальний стимул значно підвищує ефективність приватної детективної (розшукової) діяльності, є вагомою мотивацією. Наведемо окремі орієнтовні розцінки на деякі детективні послуги, які оприлюднюються у відкритих джерелах. Перевірка приміщень на прослуховуючи пристрої коштує від 10 доларів за один квадратний метр, установка прослуховуючи пристроїв - від 1000 до 2000 доларів, спостереження за чоловіком або дружиною, які підозрюються у подружній зраді - від 50 доларів за годину, комерційне шпигунство і зібрання секретної інформації від 500 доларів за добу

\footnotetext{
${ }^{1}$ Горовенко, В.В. (2001). Гражданско-правовое регулирование частной детективной и охранной деятельности: диссертация кандидата юридических наук. Екатеринбург.

2 Закон Украӥни про ліщензування видів господарської діяльності, 2015 (Верховна Рада України). Офіційний веб-сайт Верховної Ради Украӥни. $<$ https://zakon.rada.gov.ua/laws/show/222-19>.

${ }^{3}$ Бекірова, Е.Е. (2006). Правове регулювання ліцензування певних видів господарської діяльності: автореферат дисетрації на здобуття наукового ступеня кандидата юридичних наук. Донецьк, 7.

4 Закон Украӥни про підприємництво, 1991 (Верховна Рада України). Офіційний веб-сайт Верховної Ради

Украӥни. <https://zakon.rada.gov.ua/laws/show/698-12>.

${ }^{5}$ Беззуб, І. (). Приватна детективна діяльність: українські реалії та зарубіжний досвід.

$<$ http://nbuviap.gov.ua/index.php?option=com_content\&view=article\&id=2930:privatna-detektivna-diyalnistukrajinski-realiji-ta-zarubizhnij-dosvid\&catid $=8 \&$ Itemid $=350>$.

6 Чепурко, В. (2017). Частных детективов узаконили, но запретили им быть сыщиками. КП в Украине.

$<$ https://kp.ua/life/573297-chastnykh-detektyvov-uzakonyly-no-zapretyly-ym-byt-syschykamy>.
} 
Приватна детективна (розшукова) діяльність як підприємницька є інноваційною.

VI. Здійснення відповідно до укладеного договору між суб'єктами приватної детективної (розшукової) діяльності та замовниками (клієнтами). Пояснимо необхідність, з нашого погляду, включити до досліджуваного визначення термін «договір про надання детективних послуг». Насамперед зауважимо, що поняття договору про надання детективних послуг не міститься у Цивільному кодексі України, однак він уже розроблений у цивілістиці. А.Волинська його визначає, як договір, за яким одна сторона (виконавець) зобов'язується здійснити надання детективних послуг другій стороні (замовникові) на умовах і в порядку, що визначені договором, відповідно до законодавчих вимог, а замовник зобов'язується оплатити виконавцеві надання послуг та фактичні витрати, необхідні для виконання договору. А також вказує, що такий договір за офертою $є$ публічним, за моментом укладення - консенсуальним, за правами і обов'язками сторін - взаємним, за метою (отримання прибутку) - відплатним, за характером відносин між виконавцем і замовником - фідуціарним та має конфіденційний характер, за реалізацією дій фактичного i юридичного характеру - змішаним, із врахуванням ризиковості ризику - алеаторним ${ }^{1}$.

VII. Предметом договору $є$ надання замовникові широкого кола різнобічної інформації. Предметом договору про надання детективних послуг $є$ завжди різностороння інформація, яка пов'язана із видом замовленої діяльності. Зокрема, наведемо такий приклад: у разі замовлення щодо перевірки особи як потенційного бізнес-партнера 3'ясовуються біографічні та інші дані, що характеризують особу; ii ділові зв'язки, зокрема із конкурентами замовника урегіонах i за кордоном; фінансова платоспроможність, майновий стан, благонадійність, а після аналізу зібраних фактів подається відповідна інформація.

Інформація, яку аналізують об'єднання приватних детективів, ними поділяється на відкриту і закриту. Зокрема детективне агентство «Гарант», вказує, що довідка про фізичну особу, яку надають замовникові розраховується на основі аналізу та пошуку двох інформацій: відкритої і закритої. До закритих даних відноситься інформація про людину, яку надав в агентство замовник, це ім'я, фотографія, прізвище, дата і місце народження, коло знайомих, фактична адреса проживання, фінансова спроможність, наявність кредитів, судимостей і т.д. До відкритої інформації відноситься той матеріал, якій безпосередньо збирає приватний детектив, це оточення і хобі людини, сфера проводження дозвілля та інші замовленні дані. Слід враховувати, що довідка/резюме приватного детектива буде містити його особисту оцінку досліджуваного суб'єкта²

Висновки. 3 нашого погляду, основними ознаками приватної детективної (розшукової) діяльності є: діяльність окремих спеціально професійно підготовлених осіб та їх об'єднань; здійснення діяльності на законодавчій основі (водночас і відповідно до спеціального закону і відповідно до засад вітчизняного законодавства у тих сферах, в яких працюють приватні детективи); спрямування діяльності на забезпечення законних прав і інтересів фізичних та юридичних осіб; зайняття приватною детективною (розшуковою) діяльністю за дозволом уповноваженого органу; здійснення підприємницької діяльності, ознакою якою є iі платна договірна основа; iii здійснення відповідно до укладеного договору суб'єктами приватної детективної (розшукової) діяльності та замовниками (клієнтами); предметом договору є надання замовникові широкого кола різнобічної інформації.

\section{References:}

1. Bezzub, I. Pryvatna detektyvna diialnist: ukrainski realii ta zarubizhnyi dosvid [Private detective work: Ukrainian realities and foreign experience]. $<$ http://nbuviap.gov.ua/index.php?option=com_content\&view=article\&id= 2930:privatna-detektivna-diyalnist-ukrajinski-realiji-ta-zarubizhnij-dosvid\&catid=8\&Itemid $=350>$.

[in Ukrainian].

2. Bekirova, E.E. (2006). Pravove rehuliuvannia litsenzuvannia pevnykh vydiv hospodarskoi diialnosti: avtoreferat dysertatsii kandydata yurydychnykh nauk [Legal regulation of licensing of certain types of economic activity: Extended abstract of Candidates thesis of legal sciences]. Donetsk. [in Ukrainian].

3. Busel, V.T. (2004). Velykyi tlumachnyi slovnyk suchasnoi ukrainskoi movy [Large explanatory dictionary of the modern Ukrainian language]. Kyiv: Irpin. [in Ukrainian].

\footnotetext{
${ }^{1}$ Волинська, А.М. (2019). Договір про надання детективних послуг: дисертація кандидата юридичних наук. Київ, 87-91.

${ }^{2}$ Детективне агентство «Гарант». <https://garant-detektiv.com.ua/kto-takie-chastnye-detektivy/>.
} 
4. Volynska, A.M. (2019). Dohovir pro nadannia detektyvnykh posluh: dysertatsiia kandydata yurydychnykh nauk [Contract for the provision of detective services: Candidates thesis of legal sciences]. Kyiv. [in Ukrainian].

5. Gorovenko, V.V. (2001). Grazhdansko-pravovoe regulirovanie chastnoj detektivnoj i ohrannoj dejatelnosti: dissertacija kandidata juridicheskih nauk [Civil regulation of private detective and security activities: Candidates thesis of legal sciences]. Ekaterinburgh. [in Russian].

6. Detektyvne ahentstvo «Harant» [Garant Detective Agency]. $<$ https://garant-detektiv.com.ua/kto-takie-chastnyedetektivy/>. [in Ukrainian].

7. Zakon Ukrainy pro litsenzuvannia vydiv hospodarskoi diialnosti 2015 [Law of Ukraine on licensing of economic activities] (Verkhovna Rada Ukrainy) [(Verkhovna Rada of Ukraine)]. Ofitsiinyi veb-sait Verkhovnoi Rady Ukrainy [Official website of the Verkhovna Rada of Ukraine]. <https://zakon.rada.gov.ua/laws/show/222-19>. [in Ukrainian].

8. Zakon Ukrainy pro pidpryiemnytstvo 1991 [Law of Ukraine on business] (Verkhovna Rada Ukrainy) [(Verkhovna Rada of Ukraine)]. Ofitsiinyi veb-sait Verkhovnoi Rady Ukrainy [Official website of the Verkhovna Rada of Ukraine]. <https://zakon.rada.gov.ua/laws/show/698-12>. [in Ukrainian].

9. Konstytutsiia Ukrainy 1996 [Constitution of Ukraine] (Verkhovna Rada Ukrainy) [(Verkhovna Rada of Ukraine)]. Ofitsiinyi veb-sait Verkhovnoi Rady Ukrainy [Official website of the Verkhovna Rada of Ukraine]. $<$ http://.gov.ua/laws/show/254k/96-vr>. [in Ukrainian].

10. Orel, Yu.V. Deiaki pytannia pravovoho statusu pryvatnoho detektyva [Some questions of the legal status of a private detective]. <http://er.dduvs.in.ua/bitstream/123456789/1623/1/30.pdf>. [in Ukrainian].

11. Skakun, O.F. Teoriia derzhavy i prava [Theory of state and law Theory of state and law]. $<$ https://pidruchniki.com/1378122543144/pravo/zakonniy_interes_yogo_spivvidnoshennya_subyektivnim_pravom_ yuridichnim_obovyazkom>. [in Ukrainian].

12. Tsyvilnyi kōeks Ukrainy 2003 [The Civil Code of Ukraine] (Verkhovna Rada Ukrainy) [(Verkhovna Rada of Ukraine)]. Ofitsiinyi veb-sait Verkhovnoi Rady Ukrainy [Official website of the Verkhovna Rada of Ukraine]. $<$ https://zakon.rada.gov.ua/laws/show/435-15>. [in Ukrainian].

13. Tsyvilnyi protsesualnyi kodeks Ukrainy 2004 [Civil Procedure Code of Ukraine] (Verkhovna Rada Ukrainy) [(Verkhovna Rada of Ukraine)]. Ofitsiinyi veb-sait Verkhovnoi Rady Ukrainy [Official website of the Verkhovna Rada of Ukraine]. <https://zakon.rada.gov.ua/laws/show/1618-15\#n6402>. [in Ukrainian].

14. Chepurko, V. (2017). Chastnyh detektivov uzakonili, no zapretili im byt syshhikami [Private detectives were legalized, but they were forbidden to be detectives.]. KP v Ukraine [KP in Ukraine]. <https://kp.ua/life/573297chastnykh-detektyvov-uzakonyly-no-zapretyly-ym-byt-syschykamy>. [in Ukrainian].

15. Yurchenko, A.O., Usenko, A.O. (2018). Problemy lehalizatsii instytutu pryvatnoi detektyvnoi diialnosti v Ukraini [Problems of legalization of the institute of private detective activity in Ukraine]. Mizhnarodnyi yurydychnyi visnyk: aktualni problemy suchasnosti (teoriia ta praktyka) [International Legal Bulletin: current issues (theory and practice)], no. 3-4 (12-13), 133. [in Ukrainian]. 